\title{
O "X" DA VIOLÊNCIA NO PROCESSO PENAL BRASILEIRO "JUSTO": UMA ANÁLISE À LUZ DO PENSAMENTO DE DERRIDA E BOURDIEU
}

\section{Francisco Geraldo Matos Santos ${ }^{1}$ Renato Ribeiro Martins $\mathrm{Cal}^{2}$}

RESUMO: O presente artigo tem como escopo analisar o " $\mathrm{X}$ " da violência que está presente no processo penal brasileiro que almeja ser "justo". Unimos dois pensadores dos últimos anos que tem deixado o pensamento acrítico, naturalizado, para discussões teóricas densas que almejam compreender fenômenos naturalizados de forma a desconstrui-los. Nossa proposta é entender em que medida o processo penal brasileiro pós 1988 se compatibiliza ou não com a ideia de justiça, a luz de uma interpretação do pensamento de Derridá e Bourdieu que, diretamente não pesquisaram especificamente sobre uma teoria da justiça, mas propuseram críticas pontuais indispensáveis ao campo jurídico.

Palavras chave: violência; violência simbólica; Direito; campo jurídico; processo penal.

\section{THE "X" OF VIOLENCE IN THE BRAZILIAN "FAIR" CRIMINAL PROCEEDINGS: AN ANALYSIS IN THE LIGHT OF THE THOUGHT OF DERRIDA AND BOURDIEU}

\begin{abstract}
The scope of this article is an " $X$ " analysis of the violence that is present in the Brazilian criminal process that aims to be "fair". We bring together two thinkers of recent years who have to do uncritical thinking, naturalized, to carry out dense theorists that aim to understand us naturalized in order to deconstruct them. Our proposal is to understand to what extent the Brazilian criminal procedure after 1988 is compatible or not with the idea of justice, in light of an interpretation of the thought of Derridá and Bourdieu, who did not directly research specifically on a theory of justice, but proposed punctual critics indispensable to the legal field.
\end{abstract}

Keywords: violence; symbolic violence; Right; legal field; criminal proceedings.

\section{INTRODUÇÃO}

A categoria processo penal tem sido executada sem muita crítica a respeito desse instrumento em si. Quando se observa a literatura crítica que aborda o processo penal, como

\footnotetext{
${ }^{1}$ Doutorando em Direito (PPGD/UFPA), na linha de pesquisa Estudos Críticos do Direito. Mestre em Ciência Política (PPGCP/UFPA), na linha de pesquisa Teoria Política e Métodos. Especialista em Direito Processual Penal e em Direito Público, ambas pela Faculdade Prof. Damásio de Jesus (SP). Assessor Jurídico no Município de Santa Izabel do Pará. Professor Universitário. E-mail: fgeraldomatos@ hotmail.com

${ }_{2}$ Mestre em Ciência Política (PPGCP/UFPA). Especialista em Direito Processual pela Universidade da Amazônia (UNAMA). Graduado em Direito (UFPA). Auditor de Controle Externo junto ao Tribunal de Contas do Estado do Pará (TCE-PA). E-mail: renatomartinscal@ hotmail.com
} 
Lopes Júnior, a intenção reflexiva limita-se às partes ou subsistema do próprio processo penal, como por exemplo, a discussão em torno dos sistemas inquisitivo ou acusatório, como a categoria ação penal ou a própria decisão judicial, nos termos da principiologia quer seja expressa ou implícita constitucionalmente aplicável ao processo penal ou mesmo, à ausência de uma teoria das nulidades exclusiva desse instrumento.

Em suma, é indispensável ponderar que esse texto não segue essa linha de raciocínio. A proposta aqui, está relacionada à própria teoria do processo penal que - propositalmente, talvez - não enfrenta discussões dos alicerces desse campo jurídico. Partem-se das ideias universais "Processo" e "Penal", sem se perguntar sobre o por que de tal "processo penal"?

A proposta dessa pesquisa é desconstruir a noção ou o universal do "Processo Penal Justo" a partir da categoria violência. E aqui, antes de mais anda, é oportuno ponderar que a "violência" não é a violência física ou psíquica comum nas pesquisas das ciências criminais, mas como bem enfatizou Azevedo (2011), é uma violência jurídica.

Nosso problema científico fora o de responder em que medida é possível identificar a "violência" proposta por Derrida e Bourdieu na construção e consolidação do processo penal brasileiro tido como justo?

A hipótese testada fora a de que a violência - jurídica - está no próprio campo de formação de qualquer universal, dentre eles, do processo penal justo.

A metodologia utilizada fora a de um estudo teórico-normativo, que utiliza das premissas básicas de dois pensadores críticos: um no campo da filosofia, Jacques Derrida, em sua obra "Força de Lei" e o outro, no campo da sociologia, Pierre Bourdieu, com suas construções atreladas ao "campo jurídico".

Além desse introdutório, esse artigo é composto por quatro seções, mais as considerações finais.

Na próxima seção, intitulada "Conhecendo a teoria matriz da discussão", nossa proposta é apresentar os principais ensinamentos das investigações de Derrida e Bourdieu, e explicando o porquê da utilização dos mesmos.

Em sequência, propomos apresentar o " $\mathrm{x}$ " da violência como sendo uma marca do campo jurídico (ou do Direito). Aqui, explicamos o que seria essa violência e de que forma ela está naturalizada nesse campo, que acaba sendo nítida a simbolização da referida sem apontamentos críticos. 
A terceira seção refere-se às discussões acerca do processo penal brasileiro, apontando o autoritarismo como marca não apenas histórica, mas atual. A proposta é analisar a finalidade do processo penal e se é possível identificar as "violências simbólicas" nesse processo.

A última seção de desenvolvimento está relacionada à mitologia do processo penal justo. A nossa intenção é descontruir a ideia de um processo penal associado à justiça, à luz do pensamento de Derrida e do sociólogo Pierre Bourdieu.

E por fim, as considerações finais, em que se apresentam os resultados da pesquisa desenvolvida.

\section{CONHECENDO A TEORIA MATRIZ DA DISCUSSÃO: DERRIDA E BOURDIEU}

Jacques Derrida e Pierre Bourdieu são pensadores conhecidos mundialmente. Cada um com sua marca teórica específica, apresentaram suas contribuições inicialmente à filosofia e a sociologia, respectivamente, mas que depois da difusão de suas críticas, acabaram por influenciar os mais diversos campos do conhecimento.

Derrida tem sido considerado pela literatura como um dos filósofos mais traduzidos do mundo. Salanskis (2015) aponta que esse filosofo, que nasceu na Argélia em 1930, e faleceu na França em 2004, desenvolveu um metodologia específica de analisar as categorias: a desconstrução. Essa metodologia, de nenhuma forma refere-se ao ato de destruir e inutilizar os conceitos, mas entende-lo de forma minuciosa, parte por parte, de forma que após compreender todas as partes, seja perfeitamente possível e legítimo a montagem daquilo descontruído. E certamente, a categoria descontruída, a partir da reconstrução, terá novo sentido.

De forma didática, a desconstrução seria encontra dentro dos textos os princípios que os formam e os princípios da ruína também. Repito: não é uma destruição, mas uma desmontangem que permite uma montagem novamente, como se tivesse a ideia de uma recuperação da memória das coisas.

Derrida não estudou apenas um assunto, muito pelo contrário. Foi um filosofo que pesquisou sobre a cultura, sobre a arte, sobre a literatura, sobre o Direito e outros temáticas. Nesse artigo, o enfoque recai sobre sua produção acerca do Direito, mais especificamente, em sua obra Força de Lei. 
A filosofia e a literatura são centrais no pensamento derridiano. No livro, a Força de Lei, que se refere ao resultado de um colóquio organizado por Drucilla Cornell na Cardozo Law School, em outubro de 1989, que tinha como tema "A desconstrução e a possibilidade da justiça”. Nesse livro, Derrida enfatiza e se questiona acerca das distinções entre Direito e Justiça, e como é possível identificar violências nessas distinções, posto que determinada conduta pode ser considerada legal, no entanto, injusta. Derrida (2010, p. 4), inicia com um questionamento importante:

[...] será que a desconstrução assegura, permite, autoriza a possibilidade de justiça? Será que ela torna possível a justiça ou um discurso consequente sobre a justiça e sobre as condições de possibilidade de justiça? Sim, responderiam alguns, não, responderiam os opositores. Os "desconstrucionistas" têm algo a dizer sobre a justiça, algo a fazer com a justiça? Por que, no fundo, eles falam dela tão pouco? Isso lhes interessa, afinal? Não será, como alguns desconfiam, porque a desconstrução não permite, nela mesma, nenhuma ação justa, nenhum discurso justo sobre a justiça, mas constitui até mesmo uma ameaça contra o direito e arruína a condição de possibilidade da justiça? Sim, responderiam alguns; não, responderia o adversário.

Utilizando o esboço do método da desconstrução, propomos analisar partes dos textos do processo penal brasileiro e analisaremos a "justiça” que esta categoria - processo penal se propõe a executar na prática. A partir dessa análise, discutiremos com os referenciais bourdieusiano, tendo em vista que se referem a um pensamento único e detido de importância científica.

Há para Derrida, um duplo movimento da desconstrução que merece destaque: um primeiro, que se refere à responsabilidade sem limites. Para esse movimento, é necessário que para executar a desconstrução, tenhamos uma responsabilidade excessiva diante da memória, lembrando a história, a origem e o sentido, isto é, os limites dos conceitos de justiça, de lei e de direito, dos valores, normas, prescrições que ali se impuseram e se sedimentaram, permanecendo, desde então, mais ou menos legíveis ou pressupostos (DERRIDA, 2010, p. 36).

O segundo movimento, refere-se a responsabilidade da responsabilidade. Para Derrida (2010, p. 38) esse movimento refere-se:

Responsabilidade sobre o próprio conceito de responsabilidade que regula a justiça e a justeza de nossos comportamentos, de nossas decisões teóricas, práticas, ético-políticas. Esse conceito de responsabilidade é inseparável de toda uma rede de conceitos conexos (propriedade, intencionalidade, vontade, liberdade, consciência, consciência de si, sujeito, eu, pessoa, comunidade, decisão etc.). Toda desconstrução dessa rede de conceitos, em seu estado 
atual ou dominante, pode assemelhar-se a uma irresponsabilização, quando, pelo contrário, é a um acréscimo de responsabilidade que a desconstrução faz apelo.

Assim como Derrida, Pierre Bourdieu pesquisou sobre vários assuntos, não se limitando apenas ao campo da sociologia especificamente, mas também, ao campo do Direito, da literatura e da própria política. Diferentemente do pensamento derridiano que está circunscrito à análise filosófica, Bourdieu pesquisou primeiramente utilizando a etnografia, para depois chegar a estatística, por meio da socioanálise. Trata-se de um pesquisador que teve sua marca central atrelada ao empirismo, muito embora não seja um determinista, sendo, por muitos, e até por si próprio considerado, um estruturalista - Derrida, no entanto, enquadra-se no campo dos "pós-estruturalistas".

Bourdieu nasceu em 1930 na França e faleceu no mesmo país em 2002. E produziu mais de vinte livros sobre assuntos variados, sempre com a teoria da prática relacionada em suas abordagens.

O fato é que ambos são pensadores da corrente crítica, cada um com suas discussões específicas. Enquanto Derrida propôs uma análise crítica utilizando a descontrução como ferramenta, Bourdieu propôs uma crítica sociológica à própria sociologia, adotando em sua linguagem central - campo, habitus e capital -, por meio do próprio "desfazimento" um recurso à análise e compreensão dos fenômenos sociais.

A proposta deste artigo, como dito alhures, refere-se a compreender o processo penal, por meio da discussão da desconstrução derridiana e o desfazimento bourdieusiano com o intento de tecer reflexões críticas sobre algo já naturalizado no campo jurídico como instrumento de -falsa -justiça.

\section{A VIOLÊNCIA COMO MARCA DO CAMPO JURÍDICO (DIREITO): a própria} formação do Estado moderno

$\mathrm{Na}$ sociologia Bourdieusiana, é cético que o Estado - embora não definido especificamente pelo sociólogo - desempenha inúmeras fundações legitimadas que tendem a direcionar discursos, a direcionar lutas, a direcionar correntes.

Muito embora Bourdieu tenha criticado a teoria marxista no tocante a definição de Estado, que, segundo ele, se limita a explicar o fenômeno apenas com análise direcionada à "função" de defender a classe dominante - tendo em vista que Marx diz para que o Estado 
serve, mas não em que consiste a estrutura de mecanismos -, ele mesmo tem dificuldade em definir a figura do Estado (BOURDIEU, 2014).

O sociólogo, nesse diapasão, conceitua Estado, como sendo:

[...] o nome que damos aos princípios ocultos, invisíveis - para designar uma espécie de deus absonditus - da ordem social, e ao mesmo tempo da dominação tanto física como simbólica assim como da violência física e simbólica. (BOURDIEU, 2014, p. 34).

Talvez por isto, ele tenha afirmado que o Estado "é um x (a ser determinado) que reivindica com sucesso o monopólio do uso legítimo da violência física e simbólica em um território determinado e sobre o conjunto da população correspondente" (BOURDIEU, 2011,p.97).

O fato é que este Estado por ser detentor de um "metacapital", exerce um poder sobre os outros campos e sobre os diferentes tipos específicos de capital. Talvez aqui, quando Bourdieu afirma que a construção do Estado está em pé de igualdade, com a construção do campo de poder, ele utiliza da compreensão de Foucault (1979) acerca desse campo, em sua obra "A microfísica do Poder".

Bourdieu (2011), quando afirmou que a gênese do Estado é inseparável do processo de unificação dos diferentes campos sociais, ele já apresentava a importância do campo judicial como sendo o "lugar ideal" para que haja discursos, ações, práticas, tendentes a materializar essa uniformização no sentido simbólico - de conhecimento e reconhecimento como legítimo o discurso proferido pelos atores do campo judicial -. E isso tem se tornado um problema que suscita inquietações quando se verifica a incidência em um Estado que se diz democrático embora Casara (2017) negue ser este o atual estágio brasileiro -. Como um Estado pode ser democrático se os pilares da democracia não são respeitados? Como um Estado poder ser pósdemocrático se não identificamos a existência de um estágio antecessor democrático?

Almeida (2014, p.82) discorrendo sobre o campo, assim se manifestou:

O campo, porém, não é uma estrutura politicamente neutra; ao contrário, é nele que são produzidas formas de dominação específicas, bem como se reproduzem formas de dominação próprias de outros campos sociais, que se traduzem na lógica específica de cada um desses espaços sociais.

No interior de um campo, portanto, há discursos que tendem a racionalizar o modo de vida, em categorizar as pessoas, e no campo judicial, portanto, em utilizar o direito como 
instrumento de normalização, numa linguagem de Bourdieu, no sentido de ser sinônimo ao efeito de universalização. ${ }^{3}$

Foucault (2014), ao elucidar acerca de um dos elementos do dispositivo, o discurso, como sendo uma materialidade, quando da sua hipótese acerca do perigo dos discursos indiscriminadamente, assim se manifestou:

[...] suponho que em toda sociedade a produção do discurso é ao mesmo tempo controlada, selecionada, organizada e redistribuída por certo número de procedimentos que têm por função conjurar seus poderes e perigos, dominar seu acontecimento aleatório, esquivar sua pesada e temível materialidade (FOUCAULT, 2014, p. 8-9).

O discurso, então, passa a ser um mecanismo de identificação da vontade de verdade (ou poder em Foucault), que possibilita a consolidação de argumentos tendentes a universalizar o debate, ou seja, de tornar o particular em universal.

Bourdieu (2014), inclusive, faz menção que o campo jurídico é, por excelência, o típico exemplo de exercício do Poder Simbólico, nitidamente observável quando se percebe que as práticas de hierarquizar as formas de vida estão presentes no seio de um campo que tem, em tese, a função de dizer a verdade, de fazer a justiça.

E há uma correlação indiscutível entre a formação do Estado moderno e o campo jurídico. Quando dos estudos dos juristas no processo de construção do Estado, Pierre Bourdieu (2014, p. 357) assim se expressou:

\begin{abstract}
Os juristas, a meu ver, são os motores do universal, da universalização. Têm a seu favor o direito, isto é, esse discurso de pretensão universal, e essa capacidade particular, que é sua capacidade profissional, de explicar a razão, de dar as razões, de produzir razões, portanto de apresentar as coisas que são da ordem do fato - "É assim", "Não é possível", "É tolerável" etc. - à ordem da razão, por duas vias: pela evocação dos princípios jurídicos universais - não há Estado sem Constituição, por exemplo - e pelo recurso à história. Os juristas foram os primeiros historiadores do direito constitucional, os primeiros a tentar encontrar precedentes, a escrutinar os arquivos.
\end{abstract}

A partir do momento em que o campo jurídico, como sendo autônomo, dotado de uma linguagem própria, que segundo Garapon $(1999$, p. 27) é a do direito, e de uma gramática própria, a do processo, é indiscutível compreender como essa linguagem tem relação com discursos que hierarquizam as formas de vida.

\footnotetext{
${ }^{3}$ Bourdieu (1989, p. 247) pondera que "a instituição jurídica contribui, sem dúvida, universalmente para impor uma representação da normalidade em relação à qual todas as práticas diferentes tendem a aparecer como desviantes, anómicas, e até mesmo anormais, patológicas (especialmente quando a medicalização vem justificar a jurisdicização)".
} 
Se o discurso universalista, segundo Bourdieu (2014), no campo jurídico, não passa de defesa de seus interesses particulares cujo fundamento é o direito, é possível investigar se por detrás do discurso divulgado, há uma lógica da governamentalidade neoliberal.

O sociólogo Boaventura de Souza Santos (2016) traz uma discussão que se torna indispensável no atual estágio, quando se verifica que o direito pode ser mobilizado para melhorar as condições de vida dos grupos e classes sociais mais vulneráveis, no sentido de diminuir a injustiça social, a desigualdade e a discriminação. Todavia, a experiência dos últimos anos tem mostrado uma bifurcação da ordem, tendo em vista que tem se tornado extremamente difícil obter essa consolidação, na medida em que os discursos e práticas hodiernas tem se mostrado típicos casos de utilização do direito como defesa dos interesses da(s) classe(s) dominante(s) e das forças conservadoras ${ }^{4}$.

Sendo assim, com a lógica neoliberal (ou, segundo Santos (2016), o direito conservador neoliberal), esse direito não faz mais do que fixar o quadro em que uma sociedade civil baseada no mercado funciona e floresce, cabendo ao judiciário garantir que o Estado de direito seja amplamente aceito e aplicado com eficácia (SANTOS, 2016).

É por esta razão, que entendemos que o Direito esteve relacionado à formação estatal no sentido de um alicerce. Não que ele tenha criado no mundo da vida todos os efeitos do Estado, mas que ele fora o meio onde se criou juridicamente uma ficção, isto é, uma construção, uma fabricação. E essa constatação se verifica ainda mais quando temos a ideia de processo penal como o instrumento necessário que, revestido da legalidade, impõe o dever do Estado em exercer o jus puniend. O processo penal, fora criado e materializado na sociedade moderna, como sendo o verdadeiro instrumento para que o Estado possa executar sua força real simbólica em face dos "desviantes".

\section{O PROCESSO PENAL BRASILEIRO E ALGUMAS REFLEXÕES: AUTORITARISMO, VIOLÊNCIA, VERDADE.}

O autoritarismo e o processo penal não é um assunto incipiente. Se fosse pretérito, não haveria discussões hodiernas de uma questão que passou no tempo. No entanto, refere-se a uma questão que pode receber diversas formas de compreensões.

\footnotetext{
${ }^{4}$ Para Boaventura de Sousa Santos (2016,p. 22), o Brasil se encontra em uma dupla crise de regulação e de emancipação, uma crise em que o conservadorismo floresce sob o nome enganador de neoliberalismo. Para ele, o neoliberalismo não é uma versão nova do liberalismo, mas sim, uma nova identidade do conservadorismo.
} 
Gloeckner (2018) pondera que o discurso autoritário exige investigações tendentes a identificar suas bases semânticas, os regimes de enunciações. Acrescenta o autor que os elementos que estruturam o discurso autoritário não são elementos do passado e que se encontram como que adormecidos.

Esse adormecimento pode ser fruto da acriticidade doutrinária em relação às categorias mais elementares do processo penal brasileiro, permitindo com que houvesse a transmissão geracional de alguns conceitos e transformado novos elementos como se tratasse apenas de um habitus, fruto do campo jurídico. Extremamente naturalizado. Uma violência, inclusive.

Doutrinariamente, no Brasil, Gloeckner (2018, p. 48) afirma que o autoritarismo e o sistema penal foram estudados de duas formas, senão vejamos:

Do ponto de vista jurídico, mais especificamente no campo dos sistema penal, citam-se aqui duas pesquisas fundamentais no Brasil que cuidam de identificar os sentidos assumidos pela expressão autoritarismo. Para Malan, por autoritarismo poderemos compreender três conjuntos distintos de fenômenos, ou melhor: três distintas acepções do termo. Autoritarismo poderá designar: a) sistema político; b) perfil psicológico; c) ideologia política. Em outro importante estudo, Fragoso imputará ao termo autoritarismo quatro vertentes distintas: a) como abuso na constituição ou no exercício do poder; b) como regime político; c) como ideologia política; d) como mentalidade autoritária (equivalente ao autoritarismo psicológicosocial).

Desta feita, analisando o discurso e o contexto histórico que influenciou na elaboração do atual CPP, nota-se veemente, o motivo de sua marca incessante inquisitorial, que indubitavelmente exibe alguns resquícios do sistema penal do medievo.

O CPP fora promulgado em 1941, sob a égide da Constituição outorgada de 1937, que detinha inspiração forte do fascismo italiano, sendo Francisco Campos um de seus maiores intelectuais,.

Portanto, o CPP surgiu no cenário ditatorial. Na época, nos diz Giacomolli (2015, p. 146), a ideia era a de que:

Um governo forte deveria controlar a população e uma das formas de controle foi o sistema criminal. A oposição foi neutralizada, inclusive com o emprego da força física. Direitos fundamentais, Estado de Direito, democracia, respeito à dignidade, reconhecimento do outro eram vistos como obra demoníaca e de comunistas e seus defensores eram tidos como inimigos do Estado, amigos da impunidade. Nesse ambiente é que foi gestado o CPP de 1941, à margem do Estado de Direito, alheio ao Estado Constitucional legítimo, em uma época em que predominou o 
comportamento político reacionário e conservador. Influências externas, além-mar forneciam a base teórica e ideológica ao proceder brasileiro.

A elaboração do CPP se deu em um contexto histórico marcado pelo fascismo, ideologia autoritária. E por ter sido fruto de um período como este, em que o fascismo era a corrente teórica legítima da época, onde a ênfase do poderio recaia no próprio Executivo, é que o CPP se instaurou e tem se consolidado até os dias atuais. A compreensão fascista não detinha o postulado da defesa da paz. Pelo contrário, a guerra era a sua premissa básica. $\mathrm{O}$ combate, a luta, o jogo eram os postulados executáveis nesse contexto.

A noção de poder esteve relacionada a produção de verdades, conforme aduziu Foucault (2010, p. 22):

[...] O poder [...] institucionaliza a busca da verdade, ele a profissionaliza, ele a recompensa. Temos de produzir a verdade como, afinal de contas, temos de produzir riquezas, e temos de produzir a verdade para poder produzir riquezas. E, de outro lado, somos igualmente submetidos à verdade, no sentido de que a verdade é a norma; é o discurso verdadeiro que, ao menos em parte, decide; ele veicula, ele próprio propulsa efeitos de poder. Afinal de contas, somos julgados, condenados, classificados, obrigados a tarefas, destinados a uma certa maneira de viver ou a uma certa maneira de morrer, em função de discursos verdadeiros, que trazem consigo efeitos específicos de poder.

Não por outro motivo é que se interpreta o processo penal como sendo um jogo ritualístico, onde a figura do juiz imparcial - onipresente e onipotente - restringe-se à teoria. Explico: digo que se restringe a teoria na medida em que, pelas ideias do garantismo na dogmática processual penal, e as do próprio sistema acusatório, ao juiz não caberia a interferência no sentido de elucidar os fatos, tendo em vista que um dos postulados em matéria de provas no processo penal, é a incidência do axioma in dubio pro reo - ou seja, na dúvida, absolve-se o réu.

Havendo inquietações por parte do Magistrado no curso da instrução processual penal - na audiência criminal, portanto -, não caberia ao juiz fazer qualquer pergunta ao Acusado ou às testemunhas, tendo em vista que as perguntas são direcionadas à aclarar a situação fática, ou seja, pairam dúvidas, que precisam - na ótica do juízo onipresente e onipotente - ser retiradas, com um único fito: condenar o réu. Digo condená-lo, porque se no imaginário do Magistrado, houvesse o interesse em absolvê-lo, valia-se do princípio em favor do réu. 
Sobre o assunto, Coutinho (2000) sistematiza que o diferencial entre o sistema inquisitivo e o acusatório no âmbito do processo penal é identificado pelo princípio unificador, se inquisitivo (o primeiro) ou dispositivo (o outro). E o que diferencia esses princípios é a gestão da prova. Sendo o princípio unificador do sistema inquisitório o inquisitivo, observa-se a concentração do poder nas mãos do Magistrado, posto que ele detenha a gestão da prova. Nessa sistemática, o acusado é apenas um objeto de investigação, como fora no sistema penal medieval, pautado nas "santas inquisições", onde, conforme Carvalho (2015) os poderes eram concentrados na figura do juiz, dispensando o acusador, dada a necessidade apenas do tribunal de investigação.

Nesse sistema - inquisitório - o acusado é tratado como um objeto, ou um ser inferior, tanto no processo quando fora dele, tendo em vista que ele também é considerado uma ameaça a existência do "homem de bem". E é por isso que há uma legitimação de que quando juízo age "de ofício" no curso da instrução processual é marca patente do inquisitivismo.

Além disso, no sistema inquisitivo, a naturalização do habitus da prisão cautelar como sendo a regra, e a liberdade como exceção, mais uma vez elucida o fascismo no âmbito do processo penal brasileiro. Ou seja, violências que integram o habitus (BOURDIEU) ou a legitimidade (DERRIDA)

No sistema acusatório, por sua vez, há autonomização do Magistrado, que não interfere no jogo do processo, deixando às partes a tarefa de elucidar todos os fatos e apresentar todos os elementos que o convençam. E caso elas não consigam levar todos os elementos, não resta outra alternativa ao órgão julgador, senão, a absolvição do acusado.

Nesse contexto, Carvalho (2015, p. 165-166) afirma que:

Se a concepção acusatória permite pensar o processo de conhecimento como espaço cênico, como campo de diálogo, de representação e de interpretação, o momento da fala judicial é o da sentença. Assim, durante os procedimentos instrutórios, o protagonismo será exercido através do concurso ativo das partes. Acusação e defesa, em paridade de armas, movimentam-se no debate do jogo processual para dar substância às (hipó)teses probatoriamente construídas. Neste momento de formação do arsenal probatório, portanto, a posição do julgador (mediados, espectador) é fundamental, sob pena de influenciar sua condição e prejulgar o caso antes de encerradas todas as possibilidades de inserção de elementos de convicção. Encerrada a fase probatória, no momento da decisão, o magistrado toma para si a palavra das partes, passando a encenar o personagem principal da trama judiciária. 
Assim, quando a cena judiciária retrata que o protagonismo da gestão da prova é liderado pelo Magistrado, não há elementos capazes de afirmar que o sistema aplicado ao processo penal brasileiro seja o acusatório - como muitos insistem em afirmar no caso do Brasil -. Nota-se, portanto, que muito embora a ideia de estarmos em um Estado Democrático de Direito e, com isso, ser naturalizado que todos os segmento jurídicos estejam coadunados aos preceitos democráticos, não se pode afirmar na prática (política criminal) que os atos no processo penal brasileiro se valham do sistema acusatório. Em verdade, esse é o " $x$ " da violência que está estrategicamente escamoteada no discurso do processo penal brasileiro.

Pensar de modo diverso, pode acarretar o que Carvalho (2015) interpreta como sendo as máscaras que ocultam e legitimam a reprodução das violências, principalmente quando o discurso oficial é -macular- na prática a sua compatibilidade de estruturas processuais explicitamente autoritárias para com texto constitucional. Ou seja, há uma defesa incessante de que quando o Magistrado age de ofício ou inquire testemunhas ou o próprio réu de modo incisivo, apenas o está fazendo por ser o "guardião do processo". Em verdade, tal discurso acaba por confirmar a tese de Giacomolli (2015) de que no sistema inquisitivo, há uma elevação do magistrado ao ápice da pirâmide, o protagonista, o conduto do sistema, do processo. Esse é o processo penal brasileiro.

\section{O MITO DO PROCESSO PENAL JUSTO}

Derrida (2010, p. 28) aponta em "Força de Lei" que antes de falar da desconstrução, é necessário compreender duas expressões: enforceability (força executória) e to address (endereçar). Na verdade, ambos conceitos estão relacionados ao Direito e, consequentemente, ao processo penal por conseguinte.

No dizeres do filósofo:

Entre o direito, a retidão do endereço, a direção e a direiteza, deveríamos encontrar a comunicação de uma linha reta e encontrar a direção certa. Por que a desconstrução tem a reputação, justificada ou não, de tratar as coisas obliquamente, indiretamente, em estilo indireto, com tantas aspas e perguntando sempre se as coisas chegam ao endereço indicado? Essa reputação é merecida? E, merecida u não, como explica-la? (DERRIDA, 2010, p. 28)

A ideia de justiça, para Derrida, nos remete a pré-noção do endereçamento. O endereço, como a direção, como a retidão, diz algo acerca do direito, e aquilo a que não devemos faltar quando queremos a justiça, quanto queremos ser justos, é a retidão do 
endereço. Um problema perene é encontrar o endereço de uma lei, por exemplo, posto que somente em decorrência da prática é que se observa de fato o endereço para o qual a referida lei fora criada.

O processo penal, por exemplo, da forma como fora feita, advindo de um Código de Processo Penal, uma lei, inclusive, é patente que no momento da sua formulação e/ou elaboração, fora analisado o endereçamento para o qual o mesmo estava sendo criado.

Não se trata de um Código que fosse aplicado à classe economicamente favorecida, muito pelo contrário, fora elaborado exatamente para lidar com aqueles que estão incluídos no submundo, ou como disse Souza (2003) "subcidadania".

Derrida (2010, p. 41) afirma que:

Não devemos carecer de endereço, mas sobretudo, não devemos errar de endereço, não devemos nos enganar de endereço. Ora, o endereço é sempre singular. Um endereço é sempre singular, idiomático; enquanto a justiça, como direito, parece sempre supor a generalidade de uma regra, de uma norma ou de um imperativo universal. Como conciliar o ato de justiça, que deve sempre concernir a uma singularidade, indivíduos, grupos, existências insubstituíveis, o outro ou eu como outro, numa situação única, com a regra, a norma, o valor ou o imperativo de justiça, que têm necessariamente uma forma geral, mesmo que essa generalidade prescreva uma aplicação que é, cada vez, singular? Se eu me contentasse com a aplicação de uma regra justa, sem espírito de justiça e sem inventar, de certa maneira, a cada vez a regra e o exemplo, eu estaria talvez a salvo da crítica, sob a proteção do direito, agiria de modo conforme ao direito objetivo, mas não seria justo. Eu agiria, como diria Kant, em conformidade com o dever, mas não por dever ou por respeito à lei.

A questão no entanto, é o problema que não apenas o Código de Processo Penal enfrenta, mas toda a legislação como um todo: a ininteligibilidade da linguagem utilizada na redação de uma lei.

Derrida (2010, p. 32) afirma que: "Endereçar-se a outrem na língua do outro é, ao mesmo tempo, a condição de toda justiça possível". Aqui, Derrida aponta sobre a necessidade de todos os "sujeitos" serem:

"[...] capazes de entender e de interpretar; todos os "sujeitos", isto é, aqueles que estabelecem as leis, os que julgam e os que são julgados, as testemunhas no sentido largo e no sentido restrito, todos os que são garantes do exercício da justiça, ou melhor, do direito. É injusto julgar alguém que não compreende seus direitos nem a língua em que a lei está inscrita, ou o julgamento pronunciado etc. Poderíamos multiplicar os exemplos dramáticos de situação de violência em que se julga num idioma que a pessoa ou a comunidade de pessoas supostamente passiveis da lei não compreendem, às vezes não muito bem, às vezes absolutamente nada. $E$, por mais leve e sutil que seja aqui a diferença de competência no domínio do idioma, a violência 
de uma injustiça começa quando todos os parceiros de uma comunidade não compartilham totalmente o mesmo idioma. (DERRIDA, 2010, P. 33).

Aqui, e observa a violência da (in)justiça que Derrida enfatiza: julgar os leigos. No processo penal, isso se evidencia ainda mais, na medida em que os julgados além de não terem conhecimento sobre a linguagem jurídica, acabam sendo "objeto" do julgamento em um ritual completamente afastado de sua realidade: o ritual do judiciário.

Santos (2019, p. 82) pondera como o ritual do judiciário do processo penal é intencionalmente hierarquizante, posto que:

O fato é que o objetivo explícito do processo penal é hierarquizar os indivíduos, por meio de um duplo processo de discriminação entre os atores: 1) a discriminação entre os atores cujas práticas foram comprovadamente delinquentes e os outros, 2) os graus de responsabilidade, intencionalidade e periculosidade que, in fine, acabam guiando a ponderação da pena. Esta seletividade é essencial a qualquer dispositivo de repressão criminal (e de persecução penal). O princípio de hierarquização no dispositivo de repressão criminal, corresponde na realidade à estratégia fundante, explícita e oficial, deste dispositivo.

A questão, no entanto, é que a violência dessa injustiça, que consiste em julgar aqueles que não entendem o idioma ${ }^{5}$ no qual se pretende, como se diz em francês, que justice est faite [se fez a justiça], não é uma violência qualquer, uma injustiça qualquer. Essa injustiça supõe que o outro, a vítima da injustiça de língua, por assim dizer, aquela que todas as outras supõem, seja capaz de uma língua em geral, seja um homem enquanto animal falante, no sentido que nós, os homens, damos a essa palavra de linguagem (DERRIDA, 2010, p. 33-34).

Aqueles que são julgados, tem seus direitos ignorados por não serem considerados "humanos direitos", e os que defendem os seus, são, em verdade, englobados na mesma categoria e criticados de forma generalizada. E isso se materializa ainda mais com a relação mística da autoridade com que o Código de Processo Penal se fortalece.

Para Derrida (2010) direito não é a justiça. O direito é o elemento do cálculo (direito, moral e política. É justo que haja um direito, mas a justiça é incalculável, ela exige que se calcule o incalculável; e as experiências aporéticas são experiências tão improváveis quanto necessárias da justiça, isto é, momentos em que a decisão entre o justo e o injusto nunca é garantida por uma regra.

\footnotetext{
${ }^{5}$ Nos parece que quando Derrida aborda o "idioma" ele não está apenas se referindo ao idioma nacionalista, como o inglês, francês, espanhol, português etc., mas a própria linguagem como um todo, dentro do próprio idioma, como a linguagem jurídica no idioma português ou francês, por exemplo. E é nesse sentido que discutimos nesse texto.
} 
O Processo Penal e seu caráter de justiça, portanto, são distanciados. De forma que a ideia de um "processo penal justo" não passa de um mito no campo jurídico, por assim dizer. Não há a menor possibilidade de se observar um processo penal justo, quando se tem de todos os lados, instâncias estatais monopolizando os personagens e a linguagem do ritual do processo penal, em uma audiência criminal, por exemplo.

Aqui, é imperiosa a passagem em que Derrida (2010, p. 37) afirma que:

É preciso ser justo com a justiça, e a primeira justiça a fazer-lhe é ouvi-la, tentar compreender de onde ela vem, o que ela quer de nós, sabendo que ela o faz através de idiomas singulares [...]. É preciso também saber que essa justiça se endereça sempre a singularidades, à singularidade do outro, apesar ou mesmo em razão de sua pretensão à universalidade. Por conseguinte, nunca ceder a esse respeito, manter sempre vivo um questionamento sobre a origem, os fundamentos e os limites de nosso aparelho conceitual, teórico ou normativo em torno da justiça é, do ponto de vista de uma desconstrução rigorosa, tudo salvo uma neutralização do interesse pela justiça, uma insensibilidade à justiça.

Observa-se a necessidade de utilizar o primeiro movimento da desconstrução derridiano, relacionando ao processo penal brasileiro quando se intenta analisar sua justiça ou não.

É impossível se falar em justiça, quando se tem uma lei que fora estrategicamente manipulada e instaurada com a finalidade de escamotear os leigos, de subjuga-los, ainda mais, quando eles são desprovidos de qualquer arcabouço para análise da maior violência: a imposição de uma lei. Aqui nota-se perfeitamente a insuficiência decorrente do "místico da autoridade" que tanto Derrida abordou em Força de Lei. Entendemos, inclusive, que o surgimento ou manifestação desse místico de autoridade decorre do próprio campo jurídico.

O campo jurídico na teoria de Bourdieu esteve relacionada a própria configuração dos institutos tidos como públicos e oficiais.

Segundo as ideias desse sociólogo, a configuração do público como sendo o oficial ou ex officio - materializa a presença do campo, que por excelência, manifesta a intenção de universalizar os conceitos ou mesmo, de nominar o inominável. Bourdieu (2014, p. 99) fazendo alusão ao poeta ${ }^{6}$ aduz que:

O responsável das nomeações criadoras pode fazer existir coisas que não devem existir, que são inomináveis: por exemplo, ele pode fazer reconhecer a homossexualidade numa sociedade que a despreza, pode torna-la legal, nominável,

\footnotetext{
${ }^{6}$ Segundo Bourdieu (2014, p. 99) "O profeta é aquele que diz no lugar do grupo o que o grupo não pode dizer ou não quer dizer e que se automandata não provocando escândalo pelo fato de dizer coisas que até então o grupo não dizia ou não podia dizer.
} 
substituindo o insulto "veado" por "homossexual"; é um trabalho jurídico. Pode tornar nominável o inominável, o que quer dizer que se pode falar disso publicamente, mesmo na televisão, e se pode dar a palavra em público a alguém até então inominável.

A noção do oficial, do público, para Bourdieu pode assumir dois sentidos - embora ele reconheça outros inúmeros sentidos que outros sociólogos apresentaram -, o que se opõe ao particular e ao que se opõe ao escondido. No primeiro sentido, refere-se aquilo que se antagoniza ao singular, ao desprovido do comum, isto é, a tudo aquilo que não interessa à coletividade, mas sim, ao particular. E esse sentido torna-se relacional ao segundo, na medida em que o que é que público, é posto ao conhecimento de todos, ostensível, sem confidências.

Assim, o fato que distingue o privado do público no sentido deste não ser passível de ser oculto, e ser considerado como sendo o oficial, há um efeito natural de universalização, de moralização, de legítimo, típica manifestação do capital simbólico.

Se o oficial tende a universalizar, pergunta-se: qual campo tem em sua estrutura agentes que tendem a possuir determinado tipo de capital suficiente ${ }^{7}$ para dizer algo que não fora dito ou que, com os meios e instrumentos disponíveis no seio do campo, não ser questionada a legitimidade em nomear o que não fora inominável?

O campo jurídico, sem dúvida alguma. Isso porque, os juristas ou "profetas jurídicos" são detentores do capital jurídico simbolicamente legitimado socialmente. E dentre suas atribuições que ultrapassam a estrutura do campo jurídico, refletindo no campo social, acabam por dizer o oficial, cuja fundamentação está revestida no Direito, que por eles foram, aprioristicamente, criado. Tanto o é, que a própria expressão que designa preteritamente o Estado fora criada por jurista - fict iuris, embora o Estado Moderno não tenha sido "criado" pelos juristas.

Os juristas, para Bourdieu (2014) são as pessoas que afirmam o oficial, e também, tem o condão de transgredir esse oficial. Talvez por isto ele deixe bem claro a diferença entre o jurista e o sociólogo. É por isso que Bourdieu pondera que:

[...] não se pode dizer que são os juristas e os canonistas que fizeram o Estado, mas eles contribuíram imensamente. Penso que não se pode fazer uma genealogia do Estado ocidental sem fazer intervir o papel determinante dos juristas nutridos de direito, capazes de produzir essa fiction juris, essa ficção de direito. O Estado é uma ficção de direito produzida pelos juristas que se produziram como juristas produzindo Estado.

\footnotetext{
7 Suficiente aqui não no sentido de sua defesa ou menosprezo aos demais agentes, mas no sentido de legitimidade proveniente simbolicamente.
} 
Quando Bourdieu afirma que o Estado é uma ficção produzida pelos juristas, ele está relacionando apenas do ponto de vista normativo, isto é, do ponto de vista do Direito. E isso não quer dizer que tenham sido eles os criadores de fato no mundo da vida, mas que contribuíram para tanto. O importante é que os juristas foram produzidos nessa interação de produção do Estado, e que, com o tempo, passaram a autonomizar o campo jurídico do campo social como um todo.

Da mesma forma, ponderamos que os instrumentos criados pelos juristas estão revestidos da mesma simbologia que o campo jurídico como um todo. A figura do processo judicial é a manifestação desse poder simbólico.

É quase impossível, dessa forma, entender que seja verificável um processo judicial criminal justo, quer na abordagem de Bourdieu, quer na abordagem de Derrida, senão vejamos o porquê.

Bourdieu pondera que os instrumentos jurídicos são estrategicamente criados com um fim de executar violências - simbólicas, inclusive - que, comparativamente às aporias da "Justiça" de Derrida (2010) - a ideia de liberdade, decisão justa, assombração do indecidível e a urgência que barra o horizonte do saber - nos faz crer ser impossível haver um processo penal brasileiro justo.

\section{CONSIDERAÇÕES FINAIS}

A ideia de um processo penal justo não é incipiente. Há mais de trinta anos, após a consolidação da atual Constituição Federal - 1988 -, tem-se que um dos postulados que o sistema de justiça criminal deveria executar refere-se ao tão aclamado "processo penal justo".

Acontece que um dos maiores problemas que tem sido encontrado na doutrina que estuda o processo penal como um todo, refere-se às limitações científicas dos estudos apenas dos sistemas processuais penais e a -falsa- ideia de que estaríamos na égide de um sistema processual acusatório. E por isso, teríamos um processo penal justo. $\mathrm{Na}$ verdade, o fundamento do processo penal justo seria exatamente a configuração do sistema penal acusatório. Ledo engano.

O processo penal fora estruturado como uma ferramenta jurídica dos próprios juristas - que, inclusive, estiveram alicerçando a formação do Estado moderno -com o escopo de 
manifestar um procedimento que legitimasse o jus puniend estatal, que sofria limitações com o surgimento do devido processo legal e outros direitos fundamentais.

Esse processo penal, no entanto, fora estruturado sobre violências não apenas à ordem jurídica protetiva ao acusado - que nem sempre fora assim almejada -, mas as próprias ideias de justiça. O processo penal lida com hierarquizações, com estigmas, com discriminações. Lida com as mazelas sociais. Lida com a negritude. Lida - em sua grande maioria - com pessoas que não tiveram acesso a nenhum bem de consumo digno ou que não detém poder econômico algum. É esse o processo penal que tendem entendê-lo como justo.

Respondendo ao problema de pesquisa proposto, percebemos que a violência descrita por Derrida e aquela apresentada por Bourdieu quando pensou no campo jurídico, em verdade, é a mesma que assola esse processo penal que está fadado a não promover justiça. Primeiro porque não é possível ter justiça em um campo - jurídico - construído por quem estava alicerçando a formação do Estado moderno, preocupados apenas com o sucesso do próprio campo. Depois, não é possível ter um processo penal justo, porque não há no Brasil, um sistema jurídico criminal capaz de pensar as questões processuais penais como indecidíveis ou mesmo, urgentes. Nossa justiça é morosa por natureza. Trata-se de um " $x$ " da violência que estruturou e continua estruturando o processo penal que almeja um dia ser justo.

\section{REFERÊNCIAS}

ALMEIDA, Frederico de. As elites da justiça: instituições, profissões e poder na política da justiça brasileira. Revista de Sociologia e Política, v. 22. n 52, p. 77-95, dezembro.2014.

AZEVEDO, Rodrigo Ghiringhelli de. A força do direito e a violência das formas jurídicas. Revista de sociologia política, Curitiba, v. 19, n. 40, p. 27-41, outubro de 2011. Disponível em:< http://www.scielo.br/pdf/rsocp/v19n40/04.pdf>. Acessado em 15 de outubro de 2017.

BOURDIEU, Pierre. O poder simbólico. Rio de Janeiro: Bertrand Brasil, 1989.

BOURDIEU, Pierre. Razões Práticas. Sobre a teoria da ação, Campinas: Papirus, 2011 (1994).

BOURDIEU, Pierre. Meditações pascalianas. Rio de Janeiro: Bertrand Brasil, 2001.

BOURDIEU, Pierre. Sobre o Estado: curso no Collège de France (1989-1992). 1. Ed. - São Paulo: Companhia das Letras, 2014.

CARVAlHO, Salo de. Antimanual de criminologia. 6. Ed. rev. e ampl. - São Paulo: Saraiva, 2015 
CARVALHO, Salo. O encarceramento seletivo da juventude negra brasileira: a decisiva contribuição do Poder Judiciário. Rev. Fac. Direito UFMG, Belo Horizonte, n. 67, pp. 623 652, jul./dez. 2015.

CASARA, Rubens. Estado pós-democrático: neo-obscurantismo e gestão dos indesejáveis. 1. ed. - Rio de Janeiro: Civilização Brasileira, 2017.

COUTINHO, Jacinto. Introdução aos Princípios Gerais do Direito Processual Penal Brasileiro. Revista de Estudos Criminais. Porto Alegre: ITEC / Notadez, 2000.

DERRIDA, Jacques. Força de Lei. 2. Ed. Martins Fontes: São Paulo, 2010.

FOUCAULT, Michel. Em Defesa da Sociedade: curso no Collège de France (1975-1976), São Paulo: Martins Fontes, 2010.

FOUCAULT, Michel. Microfísica do Poder. Rio de Janeiro: Edições Graal, 1979.

FOUCAULT, Michel. A ordem do discurso: aula inaugural no Collège de France, pronunciada em 2 de dezembro de 1970. 24. ed.- São Paulo: Edições Loyola, 2014.

FOUCAULT, Michel. Nascimento da biopolítica: curso dado no Collège de France (19781979). - São Paulo: Martins Fontes, 2008.

FOUCAULT, Michel. Vigiar e punir: nascimento da prisão. Petrópolis: Vozes, 1999.

FOUCAULT, Michel. "O sujeito e o poder". In DREYFUS (H.), RABINOW (P.), Michel Foucault, uma trajetória filosófica: para além do estruturalismo e da hermenêutica. Rio de Janeiro: Forense Universitária, 1995, p. 231-249

FOUCAULT, Michel. Em Defesa da Sociedade, São Paulo: Martins Fontes, 2010.

GARAPON, Antoine. O juiz e a democracia: o guardião das promessas. Rio de Janeiro: Revan, 1999.

GARAPON, Antoine. Bem Julgar: ensaio sobre o ritual judiciário. Instituto Piaget: Lisboa, 1999.

GIACOMOLLI, Nereu José. Algumas marcas inquisitoriais do Código de Processo Penal brasileiro e a resistência às reformas. Revista Brasileira de Direito Processual Penal, Porto Alegre, vol. 1, n. 1, p. 143-165, 2015. http://dx.doi.org/10.22197/rbdpp.v1i1.8

GLOECKNER, Ricardo Jacobsen. Autoritarismo e processo penal: uma genealogia das ideias autoritárias no processo penal brasileiro. 1. Ed. - Florianópolis, 2018.

SALANSKIS, Jean-Michel. Derrida. - São Paulo: Estação Liberdade, 2015. 
SANTOS, Boaventura de Sousa. As bifurcações da ordem: revolução, cidade, campo e indignação. São Paulo: Cortez, 2016.

SANTOS, Francisco Geraldo Matos. A política criminal na sala de justiça: análise das audiências jurídico-penais em Belém do Pará. Dissertação (Mestrado) - Programa de PósGraduação em Ciência Política da Universidade Federal do Pará, 2019.

SOUZA, Jessé. (Não) Reconhecimento e subcidadania, ou o que é "ser gente". Lua Nova, No 29. 2003. 